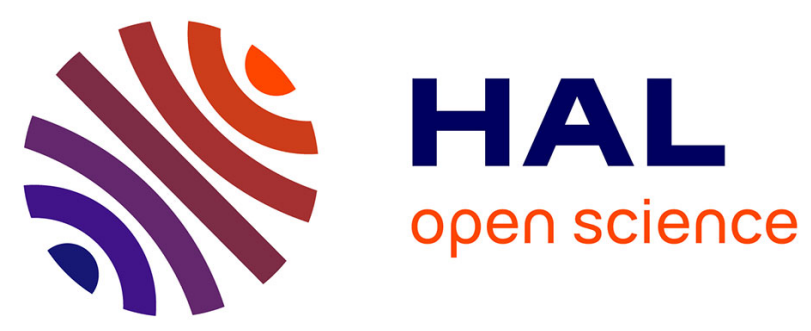

\title{
Archaeomagnetism in Italy: a compilation of data including new results and a preliminary Italian secular variation curve
}

Evdokia Tema, Ian Hedley, Philippe Lanos

\section{- To cite this version:}

Evdokia Tema, Ian Hedley, Philippe Lanos. Archaeomagnetism in Italy: a compilation of data including new results and a preliminary Italian secular variation curve. Geophysical Journal International, 2006, 167 (3), pp.1160-1171. 10.1111/j.1365-246X.2006.03150.x . insu-00266626

HAL Id: insu-00266626

https://hal-insu.archives-ouvertes.fr/insu-00266626

Submitted on 6 Jul 2017

HAL is a multi-disciplinary open access archive for the deposit and dissemination of scientific research documents, whether they are published or not. The documents may come from teaching and research institutions in France or abroad, or from public or private research centers.
L'archive ouverte pluridisciplinaire HAL, est destinée au dépôt et à la diffusion de documents scientifiques de niveau recherche, publiés ou non, émanant des établissements d'enseignement et de recherche français ou étrangers, des laboratoires publics ou privés. 


\title{
Archaeomagnetism in Italy: a compilation of data including new results and a preliminary Italian secular variation curve
}

\author{
Evdokia Tema, ${ }^{1}$ Ian Hedley ${ }^{2}$ and Philippe Lanos $^{3}$ \\ ${ }^{1}$ Dipartimento di Scienze della Terra, Università di Torino,via Valperga Caluso 35, 10125, Torino, Italy. E-mail: evdokia.tema@unito.it \\ ${ }^{2}$ Laboratoire de Pétrophysique, Département de Minéralogie, Université de Genève, Rue des Maral chers 13, CH-1205, Genève, Switzerland \\ ${ }^{3}$ CNRS, UMR 6566 Laboratoire d'Archéomagnétisme, Université de Rennes 1, Campus scientifique de Beaulieu, CS 74205, F35042, Rennes Cedex, France
}

Accepted 2006 July 20. Received 2006 July 19; in original form 2006 March 13

\begin{abstract}
SUMMAR Y
Published Italian archaeomagnetic data are combined with new data from the Genève and Torino laboratories. A total of 74 directional data is presented with age estimates falling between $1300 \mathrm{BC}$ to $1600 \mathrm{AD}$, including results from volcanic deposits of unquestionable age. The data set has been analysed using the Bayesian stochastic approach for curve building to produce a preliminary Italian secular variation (SV) curve. Comparison with the French SV curve shows a general agreement but some significant differences are also observed. The new Italian SV curve can be used for archaeomagnetic dating of Italian artefacts, even though caution must be paid for the period 9th-12th century AD and times older than 8th century BC, when only few data are available and error envelopes are large.
\end{abstract}

Key words: archaeomagnetism, Bayesian statistics, Italy, secular variation.

\section{NTRODUCTION}

During the last few decades archaeomagnetic studies have attempted to establish the variation of the Earth's magnetic field prior 16th century, when the earliest direct measurements started. Although Italy has a rich archaeological heritage, Italian archaeomagnetic data are still sparse in comparison to those of other countries where the quantity and quality of archaeomagnetic data allow the construction of reliable secular variation (SV) curves; e.g. France (Thellier 1981; Bucur 1994; Gallet et al. 2002), Bulgaria (Kovacheva 1997), United Kingdom (Clark et al. 1988; Tarling \& Dobson 1995; Batt 1997), Hungary (Márton 1996, 2003; Márton \& Ferencz 2006) and Germany (Schnepp et al. 2004; Schnepp \& Lanos 2005). Clearly the acquisition of new data from Italian sites is needed to enrich the Italian database and to establish a SV curve for Italy before 1640 AD, when Athanasius Kircher made the first direct measurement of both declination and inclination of the Earth's field in Rome (Cafarella et al. 1992).

This paper presents 28 new directional results from archaeological sites in Italy (Fig. 1) that have been investigated in recent years by the Torino and Genève laboratories. They have been added to a compilation of the existing Italian archaeomagnetic data and a preliminary SV curve derived by Bayesian statistical modelling is proposed.

\section{NEW ARCHAEOMAGNETIC RESULTS}

\section{Torino laboratory}

During the last $2 \mathrm{yr}$, samples have been collected from three sites in southern Italy (Vagnari, Ascoli Satriano, Canosa-Nos. 24, 25 and 15, respectively, Table 1) and two in central Italy (Foro Traiano situated in the centre of Rome-Nos. 3 and 14, Table 1). In all cases the material sampled consists of bricks and tile fragments collected in situ from the main structure of the kilns (Fig. 2). Hand samples were oriented in the field using an inclinometer and both magnetic and sun compass whenever possible. In the laboratory the samples were cut into cylindrical specimens of standard size (diameter $=$ $25.4 \mathrm{~mm}$, height $=22 \mathrm{~mm}$ ). For all structures a well-constrained age was available based on archaeological evidence.

All magnetic measurements were carried out at the palaeomagnetic laboratory of Torino. The natural remanent magnetization (NRM) was measured for all specimens using a JR-5 spinner magnetometer and the characteristic remanent magnetization (ChRM) was isolated using both thermal and alternating field (AF) stepwise demagnetization. The demagnetization diagrams (Fig. 3) for all the structures studied show the presence of only one very stable component of magnetization with no or very minor secondary components of probably viscous origin that are easily removed at low temperature $\left(<200^{\circ} \mathrm{C}\right)$ or in weak applied field $(<20 \mathrm{mT})$. The ChRM is well defined and can be taken as representative of the primary remanence acquired during the last firing of the structure. As a standard routine, three specimens were stepwise demagnetized from each independently oriented sample and their ChRM directions were obtained by principal component analysis using the PaleoMac program (Cogné 2003). They were used for the calculation of the sample's and subsequently the site's mean direction using Fisher statistics (Fisher 1953).

Magnetic mineralogy was investigated by isothermal remanent magnetization (IRM) measurements (Fig. 4a) and thermal demagnetization of IRM components (Lowrie 1990) (Fig. 4b). In most cases saturation is reached in low fields $(200-300 \mathrm{mT})$ and almost 


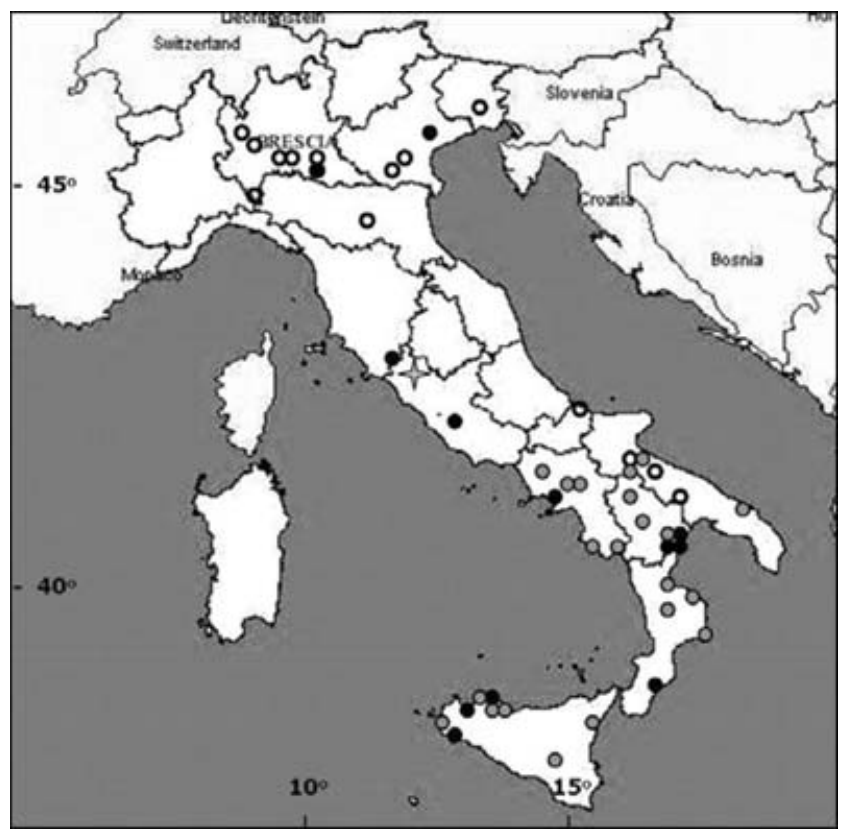

Figure 1. Locations of Italian archaeomagnetic sites. Symbols: open dot = new site studied in the present paper; full dot $=$ site from literature: black dot $=$ site where more than one independent structure have been studied, grey dot $=$ one structure studied; grey star $=$ Viterbo reference site.

all magnetization is erased at temperatures between $520-580^{\circ} \mathrm{C}$, indicating a soft, low-coercivity mineral as the dominant remanence carrier; accordingly a magnetite near mineral with impurities or maghemitization.

\section{Genève laboratory}

As part of an on-going research project in archaeomagnetism 23 burnt structures have been sampled in Italy over a period of $12 \mathrm{yr}$. They consist mainly of hearths and kilns.

At the first site (San Vincenzo, Galliano-No. 12, Table 1) large samples were taken $(6 \times 6 \times 4 \mathrm{~cm})$ moulded in plaster of Paris, but subsequent structures were sampled using the glued plastic disc method established by Clark et al. (1988). The remanence of the resulting small (18 mm diameter) cylinders of baked clay was measured using a Digico/Minispin fluxgate magnetometer. In the case of three of the large kilns (Massinigo and Carlino-Nos. 74 and 19, 20, Table 1) pieces of tiles were taken, which were later cored to give standard $25 \mathrm{~mm}$ diameter cylinders. In calculating the mean direction for the entire kiln the hierarchy of specimens from samples was maintained. All samples were oriented in the field using a magnetic compass and an electronic inclinometer, and wherever possible the orientation was also checked with a sun compass. Most specimens were subjected to a viscosity test (Thellier \& Thellier 1959) and some of the structures were treated using AF or partial thermal demagnetisation. The Thellier type viscosity test consisted of inverting the specimen with respect to its original orientation in the field and leaving it for one month in the laboratory field. Specimens that changed their remanence more than 10 per cent were rejected.

A description of the archaeological structures studied is given in the appendix.

\section{ITALIAN ARCHAEOMAGNETIC DATABASE}

Evans \& Hoye (2005) have recently published a summary of the archaeomagnetic investigations they carried out in Italy over the last $20 \mathrm{yr}$. This included 29 sites from southern Italy and is the only systematic account in the literature. Around 10 other papers dealing with single sites have been published by various authors in a variety of national and international journals. Other data are still confined to excavation reports.

The present paper presents a total of 74 directional results from archaeological material (Table 1) derived from a systematic compilation and supplemented by the new results presented in the previous section. The table includes:

(1) Site name and geographical coordinates. The coordinates, when missing in the original publication, refer to the town or village nearest to the archaeological site. The location error is no more than few kilometres and is negligible in relocating the data to the reference site. The geographical distribution of the sites (Fig. 1) shows that they are concentrated in southern Italy, whilst central and northern Italy are only poorly represented. In fact, no data from northern and central Italy have been published previously.

(2) The age of the sampled structure, mainly based on archaeological evidence. Only four thermoluminescence and three ${ }^{14} \mathrm{C}$ ages are available; all of them from the new sites. From the age uncertainty of each structure, a mean age was calculated that is used as the time coordinate to draw the declination and inclination plots. Data from a few sites with uncertain or no age have also been included; these do not contribute to the SV curve, but could be useful for future studies.

(3) Type of material studied. In most cases this was kilns, furnaces, and in situ fragments of tiles and bricks from fired structures. In some cases mural paintings or small hearths have also been studied. The results from sets of bricks, which only give the inclination value, have also been included in Table 1. A structure/context number is included when available.

(4) Number of independently oriented samples, N . The number of specimens measured from each structure $(n)$ is given within brackets. However, in the majority of the original papers information regarding the distinction between specimens/ samples is not clear or even lacking.

(5) The technique used to derive the archaeomagnetic direction, usually AF or thermal stepwise demagnetization. In some cases only NRM measurements and Thellier viscosity tests (Thellier \& Thellier 1959) have been performed.

(6) The site mean archaeomagnetic direction $(D, I)$, together with the values of the $\alpha_{95}$ and $k$ parameters of Fisher's statistics, and the direction relocated to the Italian reference station at Viterbo $\left(D_{r}, I_{r}\right)$. Relocation was performed using the virtual geomagnetic pole (VGP) method (Noel \& Batt 1990) in which the site $D, I$ values are used to calculate the VGP position (inclined geocentric dipole) and the VGP is then used to calculate the relocated values to a common reference point, in this case $D_{r}, I_{r}$. Lanza \& Zanella (2003) proposed a point near Viterbo (lat. $42^{\circ} 27^{\prime} \mathrm{N}$, long. $12^{\circ} 02^{\prime} \mathrm{E}$ ) as the most suitable reference site for Italy, as it gives the smallest relocation error both in $\mathrm{D}$ and $\mathrm{I}\left(\right.$ less that $1^{\circ}$ ), wherever the original site is situated in Italy.

(7) The original reference.

In additional to the archaeological remains, the Italian active volcanoes can contribute to the SV curve, particularly when the eruptions are described in written sources; the most famous being the two 


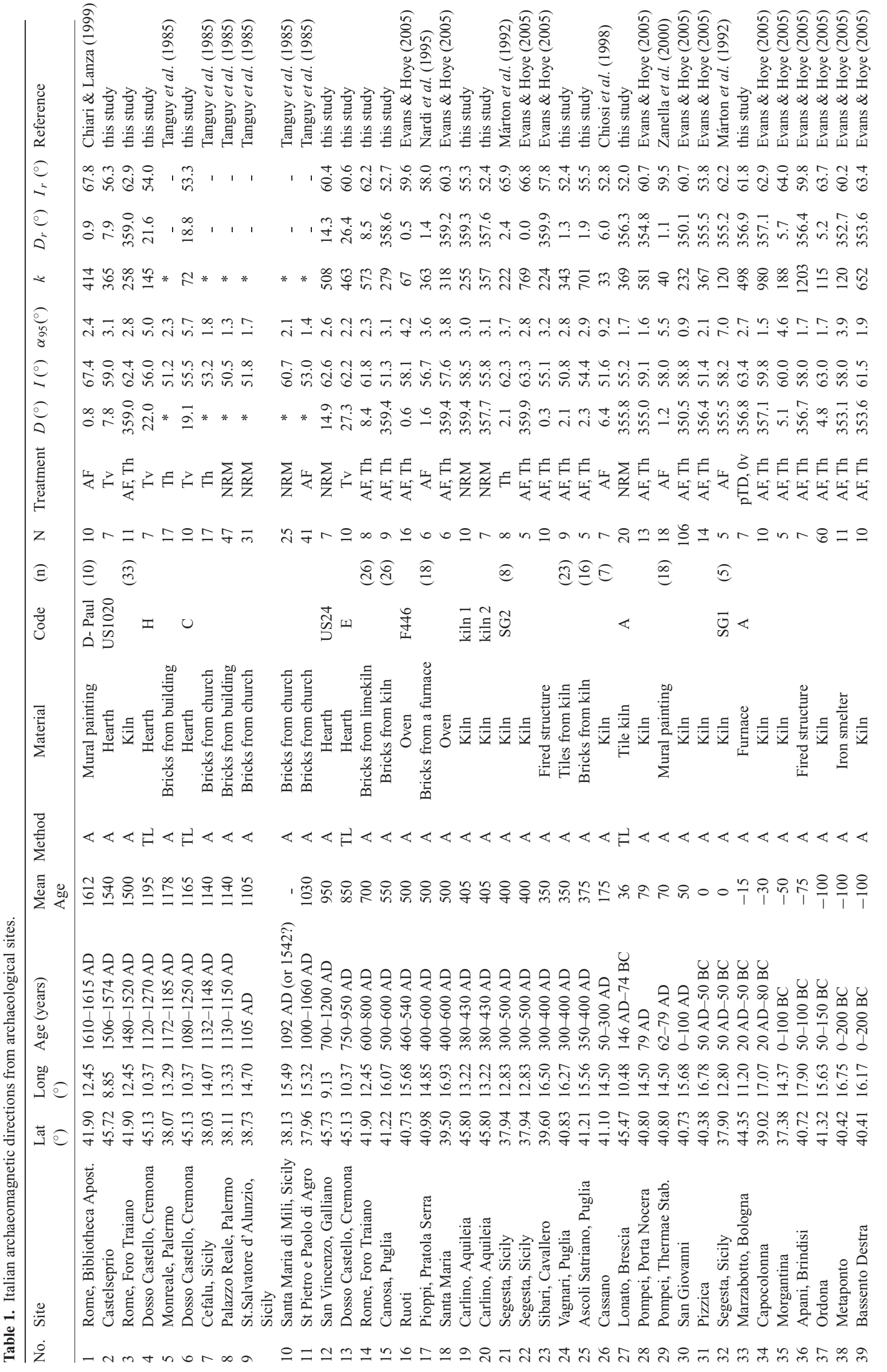




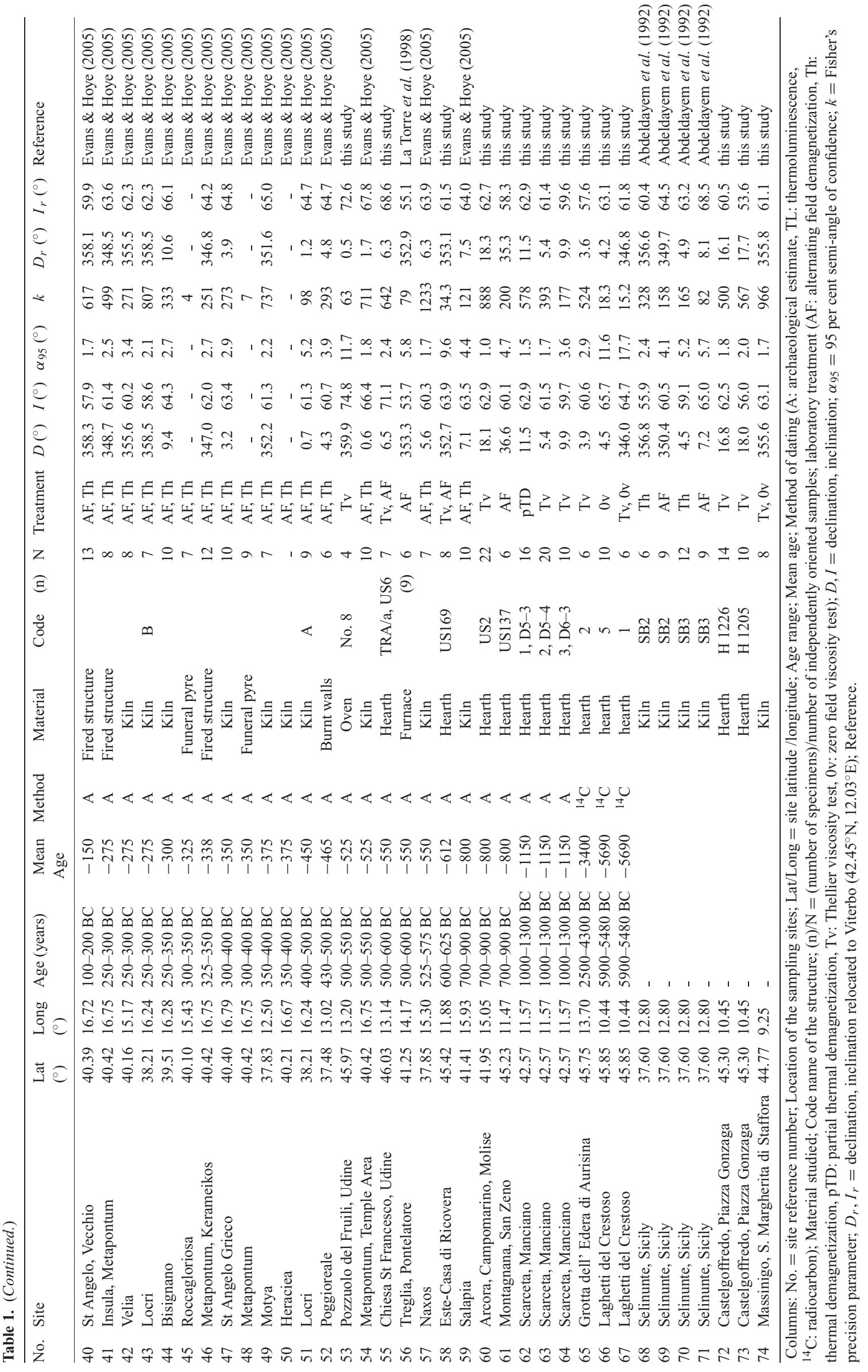




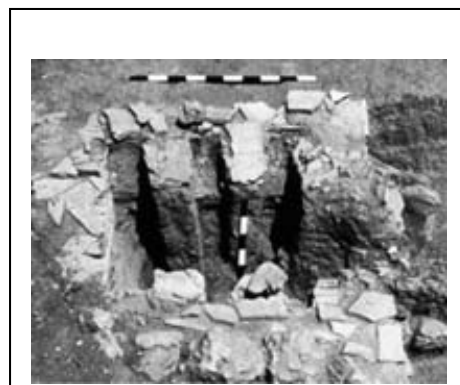

(a)

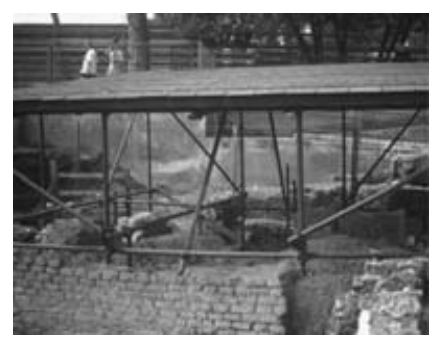

(d)

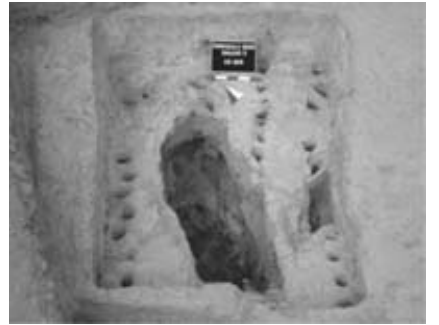

(b)

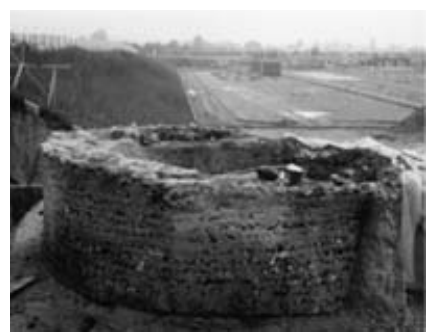

(e)

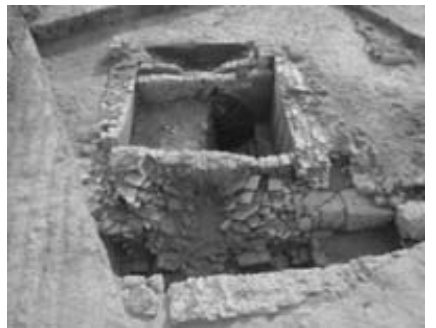

(c)

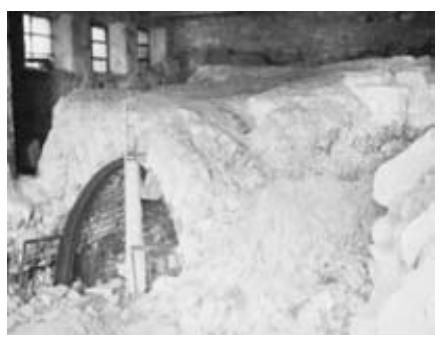

(f)

Figure 2. Pictures of some of the new studied structures (a) Vagnari (No. 24), (b) Ascoli (No. 25), (c) Canosa (No. 15), (d) Roma (No. 3), (e) Lonato (No. 27) and (f) Massinigo (No. 74). (Numbers within parenthesis refer to Table 1).

letters of Pliny the younger with the account of the 79 AD eruption of Vesuvius which destroyed the Roman cities of Pompeii and Herculaneum. However, combination of volcanological and rock-magnetic investigations (Tanguy et al. 2003; Principe et al. 2004) has shown that the age traditionally attributed to lava flows on the ground of written reports is in several cases inconsistent with the archaeomagnetic direction of the rocks. Many lava flows have thus been assigned a new, archaeomagnetic age on the grounds of comparison with the French SV reference curve. These data are, therefore, not used to construct the Italian SV curve. On one hand, introducing archaeomagnetically dated values in an archaeomagnetic reference curve would be a circular reasoning; on the other hand they would bias any comparison between the Italian and French curves, having their new ages actually derived from the French SV curve. As a cautionary criterion, we only use the data from volcanic rocks of undisputed, certain age, i.e. those of the Mt. Vesuvius 1631 AD (pyroclastic flow), Mt. Arso (Ischia) 1302 AD, Pollena (Vesuvius) 472 $\mathrm{AD}$ and Pompeii (Vesuvius) $79 \mathrm{AD}$ eruptions (Table 2).

\section{DISCUSSION ON THE ARCHAEOMAGNETIC DATA}

The Italian archaeomagnetic data relocated to Viterbo $\left(D_{r}, I_{r}\right)$ are presented in Table 1 and plotted in Fig. 5. Results from volcanic rocks emplaced by eruptions of certain age (Table 2) have been used as time markers as previously discussed. The plots also show the SV curve for the last four centuries drawn from direct measurements (Lanza et al. 2005), derived from the historical Italian catalogue (Cafarella et al. 1992) and the Jackson et al. (2000) global database. The irregular time distribution of Italian archaeomagnetic data is clearly visible (Fig. 5). The majority of data are concentrated in the period from $600 \mathrm{BC}$ to $600 \mathrm{AD}$ with a two centuries gap from 100 to $300 \mathrm{AD}$. Outside of this period, data are scarce and for some centuries (e.g the 9th century BC and 14th century AD) are absent. For the periods for which more data are available, they are generally consistent with each other, even if some discrepancies do occur. It is interesting that in some cases the mean direction seems to be in very good agreement with the other data from the same time period even when characterized by high measurement errors (e.g. structure 53, Table 1 , with angle $\alpha_{95}=11.7^{\circ}$ ). The directions from the volcanic rocks with no age uncertainty represent reference points and are in excellent agreement with the coeval archaeomagnetic data. Data for the last centuries (14th-15th century AD) seem to follow the general trend of the SV of the geomagnetic field as indicated by historical measurements of the last $400 \mathrm{yr}$, although declination values from data of 15 th century are slightly lower than expected.

The Italian data have been relocated to Paris using the VGP method and plotted (Fig. 6) against the French SV curve (data set from Gallet et al. 2002, treated with Lanos algorithm, Lanos 2004). The French SV curve is shown with its 95 per cent error envelope while for the Italian data the time and measurement errors are not shown for legibility reasons. The data fit well to the French curve and most of them are inside its error bars. However, some points fall far from the curve. Such discrepancies may be due to various reasons such as uncertainty in the age of the structures, measurement errors, anisotropy effects etc. It is interesting to observe (Fig. 6) that the declination values of the new sites of Vagnari, Ascoli, Canosa and Rome fit very well to the French curve, whilst their inclination values are lower than expected for their archaeological age. Systematic measurements of the anisotropy of magnetic susceptibility (AMS) have been done for all specimens; anisotropy of isothermal (AIRM) and anhysteretic (AARM) remanent magnetization have been studied for selected specimens. Equal area projections of the three principal anisotropy axes show a well-developed magnetic foliation (Fig. 7a) with the maximum and intermediate susceptibility axes lying in the tile/brick plane and the minimum axis perpendicular to this plane (Fig. 7b). As in most cases the tiles and bricks sampled were in a horizontal position in the kilns, these anisotropy results suggest a possible systematic shallowing of the inclination values. The inclination values of these five structures (Table 1) could, therefore, be slightly underestimated. Nevertheless, there are still some 


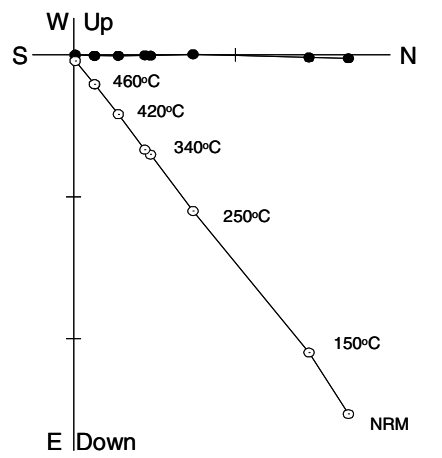

A2A-IS

Scale: $1 \mathrm{e} 0 \mathrm{~A} \mathrm{~m}^{-1}$

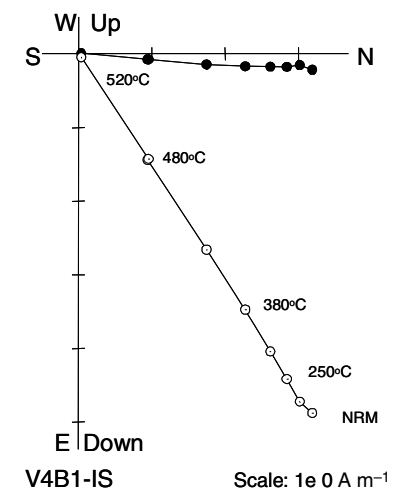

(a)
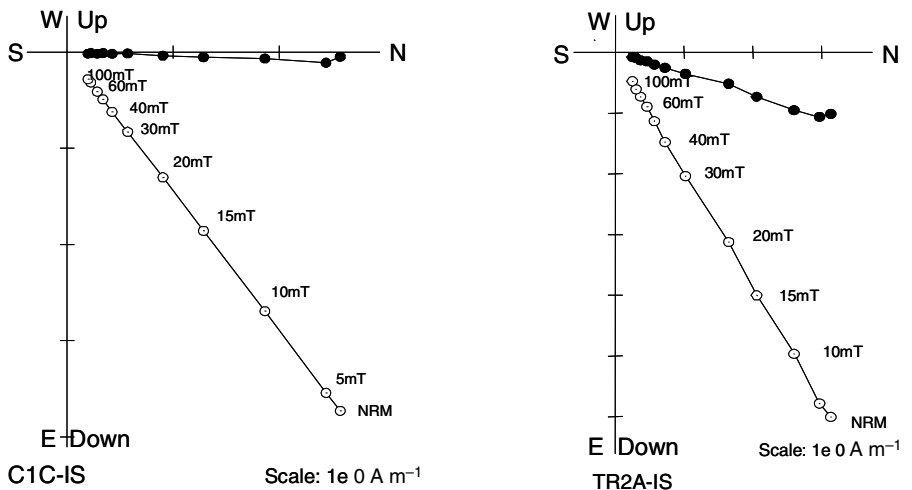

(b)
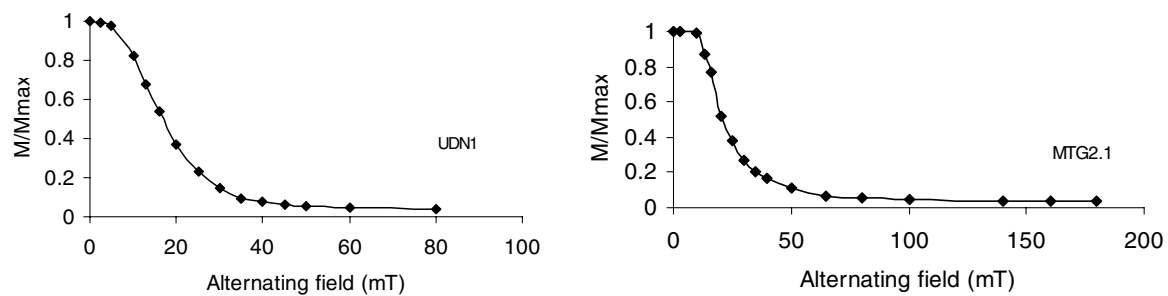

(c)

Figure 3. (a), (b) Zijderveld diagrams from stepwise thermal (a) and AF (b) demagnetization of specimens from the kilns at Ascoli (No. 25), Vagnari (No. 24), Canosa (No. 15) and Roma (No. 14), respectively. Symbols: full dot $=$ declination; open dot $=$ apparent inclination; figures: peak-field (mT) or temperature $\left({ }^{\circ} \mathrm{C}\right)$ values. (c) Normalized intensity decay during AF demagnetization of specimens from the hearth at Chiesa San Francesco (UDN1- No. 55) and Montagnana (No. 61).

data that show incompatible inclination values even when there is no evidence for important anisotropy effects (e.g. structures Nos. 21, 22 Table 1). As discussed by Evans \& Hoye (2005), these data come from the same structure independently studied by two different groups, both obtaining very similar results that are nonetheless far from the curve. A possible explanation for such a deviation could be a younger age than suggested by archaeological evidence currently available (Evans \& Hoye 2005).

\section{BAYESIAN FRAMEWORK FOR THE CONSTRUCTION OF CALIBRATION CURVES: A PRELIMINARY ITALIAN SECULAR VARIATION CURVE}

In order to build a $\mathrm{SV}$ curve for a given region, a long sequence of numerous and well-dated data should be available. However, in archaeomagnetism, it is often the case that the data are unevenly distributed in time and space and characterized by varying precisions depending on measurement errors as well as on errors related to the dates used as reference points. In such a case, the aim is to consider the given data and their potential errors and find the best-corresponding statistical model to describe their variations in a smoothed way. To achieve this goal different methods have been used; the moving window technique (Kovacheva \& Toshkov 1994; Kovacheva et al. 1998; Batt 1997), the bivariate Le Goff statistics (Le Goff et al. 1992; Daly \& Le Goff 1996; Le Goff et al. 2002), the Bayesian statistical framework (Buck et al. 1996; Lanos 2004; Lanos et al. 2005). In the present paper, in order to obtain a smooth SV curve for Italy, the hierarchical Bayesian modelling based on roughness penalty has been used (Lanos 2004). This model compares data from different methods, prior dates and parameters, and relative chronology (stratigraphy) information and 
(a)
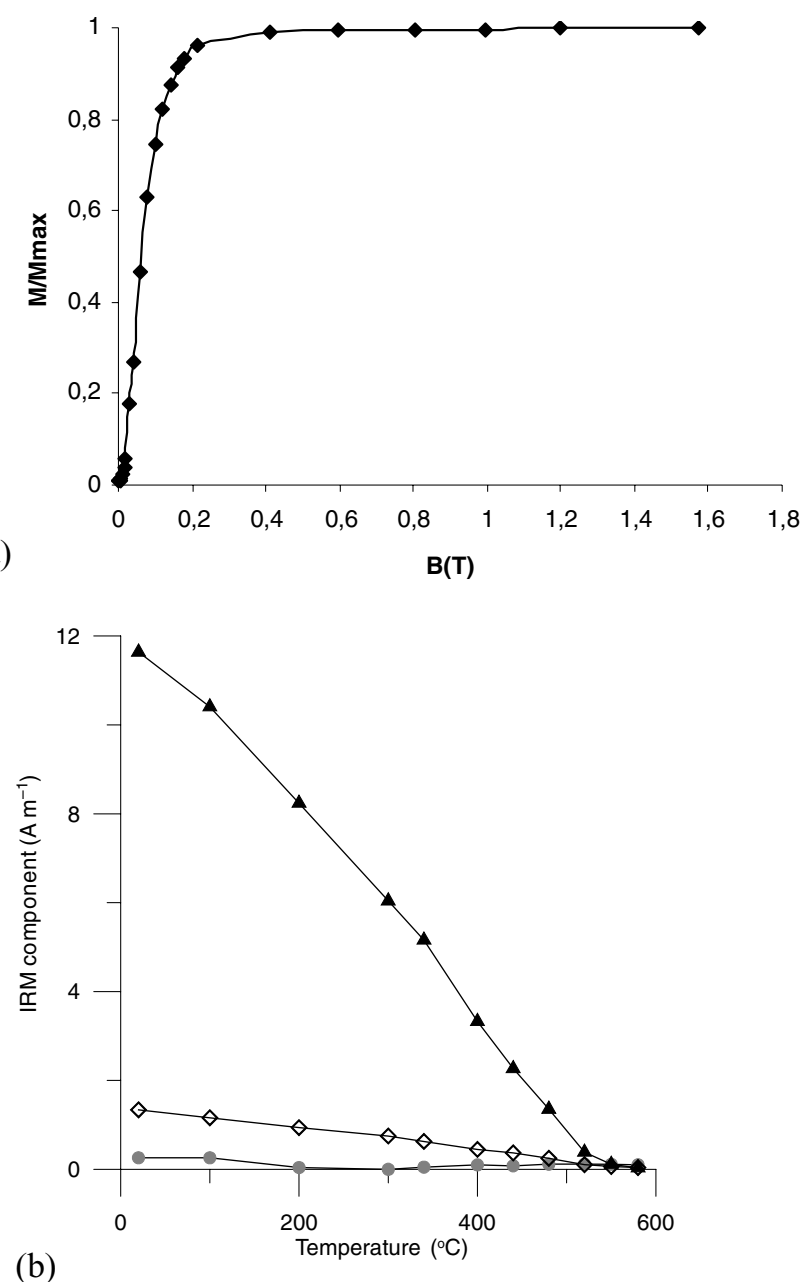

Figure 4. (a) Isothermal remanent acquisition (IRM) curve (b) thermal demagnetization of IRM components (specimens from the structures Nos. 14 and 3-Table 1). Symbols: black triangle $=$ low-; open diamond $=$ intermediate-; grey dot $=$ high-coercivity component.

the use of penalized maximum likelihood from smoothing univariate, spherical or 3-D time-series data allows representation of the $\mathrm{SV}$ of the geomagnetic field over time. The smoothed curve obtained (which takes the form of a penalized natural cubic spline) provides an adaptation to the effects of variability in the density of reference points over time. Since the model takes into account all the known errors in the archaeomagnetic calibration process, a functional highest-posterior-density envelope on the new curve can be obtained.

For the construction of the SV curve for Italy, referred to Viterbo, 65 directional results ranging in time from $1300 \mathrm{BC}$ to $1700 \mathrm{AD}$ have been used, i.e all those with complete information: declination, inclination and age (Table 1) and data from volcanic rocks of certain age (Table 2). No cut-off criterion based on the $\alpha_{95}$ angle of confidence has been applied; however, all data used for the construction of the curve have precision parameter $k>30$. Historical measurements for the last four centuries have not been included in the construction of the curve with the Bayesian model as their high precision would bias the calculation of the curve, but they have been plotted together with the final curve in Fig. 8. This figure shows the obtained declination and inclination curves together with their 95 per cent error envelope from Bayesian calculations and the raw data. In general, almost all

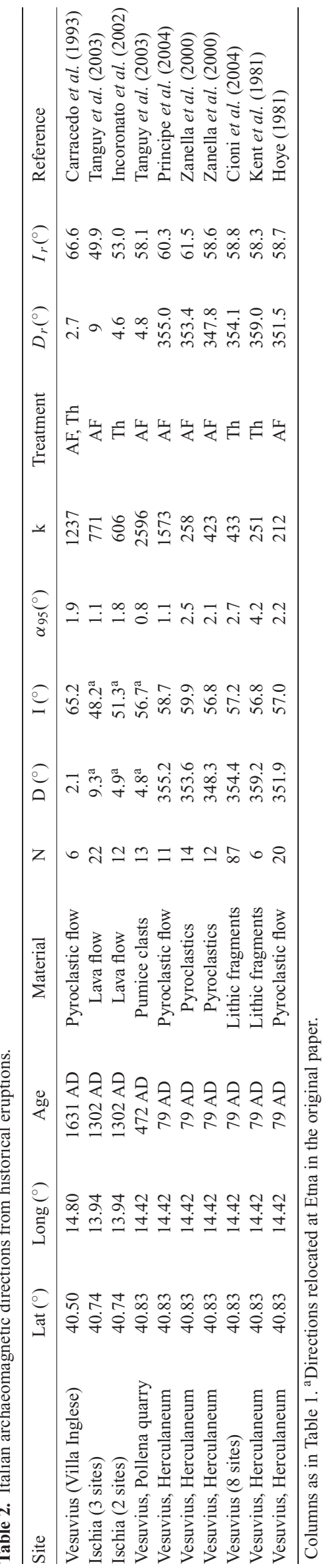

(c) 2006 The Authors, GJI, 167, 1160-1171 Journal compilation $(2006$ RAS 


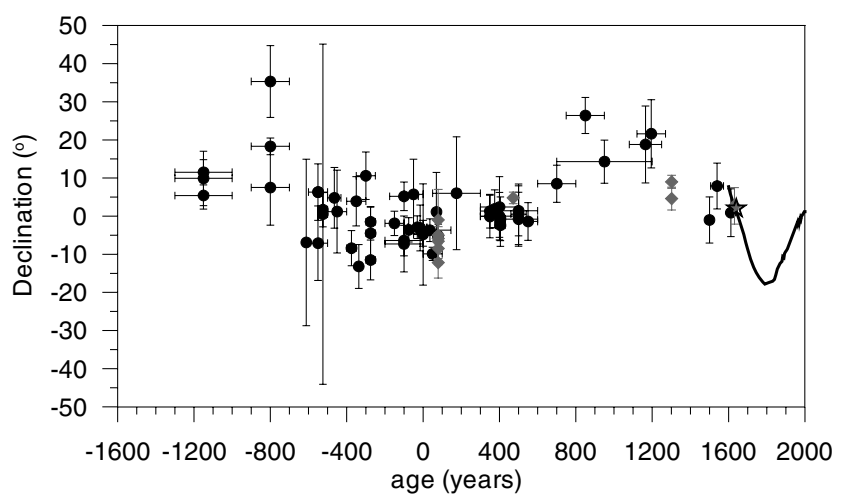

(a)

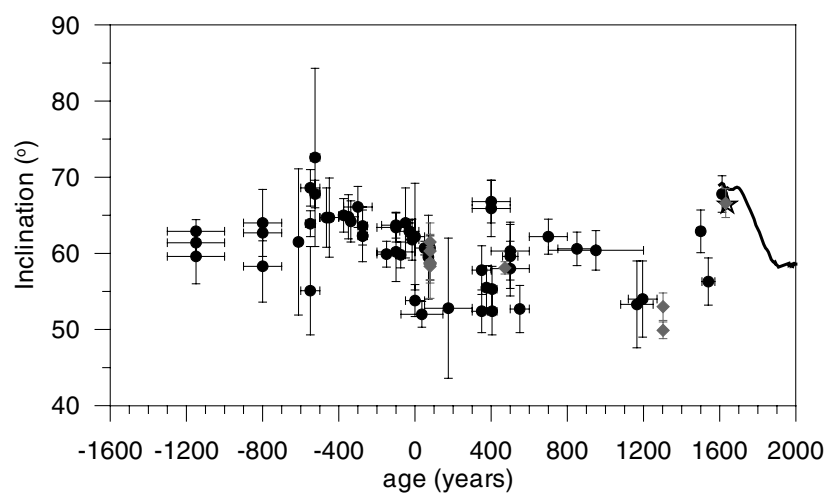

(b)

Figure 5. Declination (a) and inclination (b) values of Italian archaeological sites and volcanic rocks plotted versus age together with measurement errors $(\mathrm{dD}, \mathrm{dI})$ and age uncertainties. All directions are reduced to the reference site Viterbo $\left(42.45^{\circ} \mathrm{N}, 12.03^{\circ} \mathrm{E}\right)$. Symbols: black dots = archaeomagnetic data; grey diamonds $=$ volcanic data; star $=1640$ measurement in Rome by Kircher; black line $=$ secular variation curve for Italy during last four centuries (see text for explanation).

data are well represented by the smoothed curves. As expected for the periods for which many data exist (e.g. 79 AD), the curves are better defined with narrow error envelopes while for those time periods with few or no data the curves are more roughly estimated. As Bayesian calculations take into consideration both the measurement and time uncertainties, it is probable that for those periods poorly covered by the data the curve is affected by an over-smoothing effect. Historical measurements seem to fit the curve within its error envelope but for both declination and inclination they tend to coincide with the upper error margin. Inclination measurement done by Kircher at Rome in 1640 is around $2^{\circ}$ lower than that derived from Jackson's model (Jackson et al. 2000) for the same period. This coincides better with the trend of the curve for the beginning of the 17th century suggesting that the inclination for this time period maybe over estimated by Jackson's model, as already discussed by Lanza et al. (2005).

In Fig. 9 the Italian reference SV curves for declination and inclination are plotted together with the French reference curves (data set from Gallet et al. 2002, relocated to Viterbo). Comparison of the curves shows an agreement in the general features taking into consideration the error limits. However, some differences are apparent, mainly in the inclination values. The Italian curve has less abrupt maxima and minima and more smoothed changes compared with the French curve. The inclination maxima at around the 7 th century $\mathrm{BC}$ and the 8th century $\mathrm{AD}$ shown at the French curve

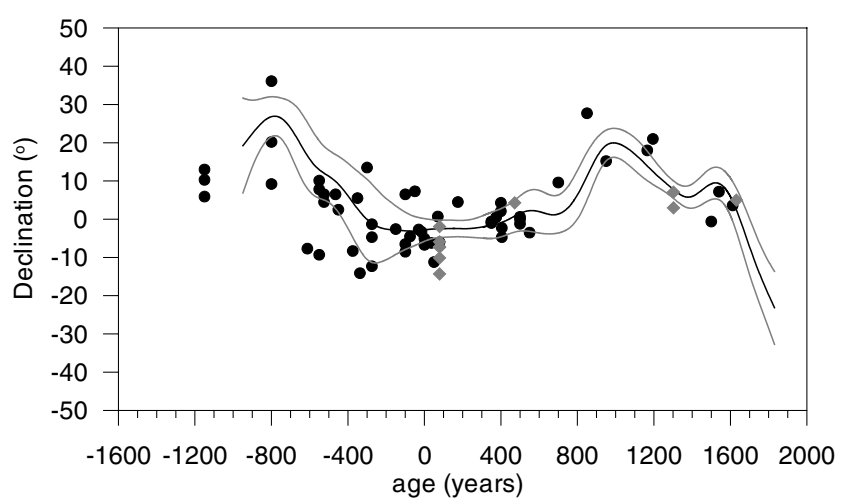

(a)

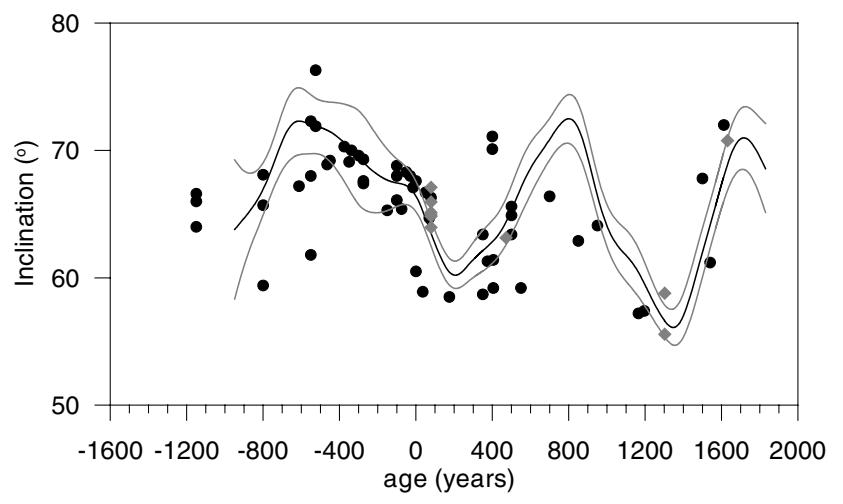

(b)

Figure 6. Declination (a) and inclination (b) values of Italian data (same as in Fig. 5) plotted versus the French SV curve (black line surrounded by the 95 per cent error envelope in grey colour - data set Gallet et al. 2002). All directions are reduced to Paris. Symbols: black dots $=$ archaeomagnetic data; grey diamonds $=$ volcanic data .

are also observed in the Italian curve but about $5^{\circ}$ lower. Furthermore the Italian inclination curve shows a minimum around the 13th century AD while in the French curve it is more abrupt and occurs over a century later. Such differences could be due to the smoothing effect of Bayesian interpretation on the Italian data in particularly for those periods with a small number of data, such as 10 th-14th century AD. However, similar, less abrupt changes in inclination have been also noticed in the German SV reference curve (Schnepp \& Lanos 2005) when compared to the French SV curve.

\section{CONCLUSIONS}

These new directional results from Italian archaeological sites are a significant contribution to the Italian archaeomagnetic database as they cover time periods, for example, 1300-700 BC and 600-1600 $\mathrm{AD}$, that were previously poorly studied, as well as geographical areas, for which no data have been previously published (northern Italy). Compilation of the data shows that they range in time from $1300 \mathrm{BC}$ to $1700 \mathrm{AD}$ but with several periods that need further study. Their geographical distribution covers almost the entire Italian peninsula, although most of data are far more concentrated in the south, emphasizing the need for obtaining new results from central and northern Italy. The total number of data, even though not as numerous as those from France, Bulgaria or UK, can now be considered sufficient for a preliminary Italian SV curve for the 


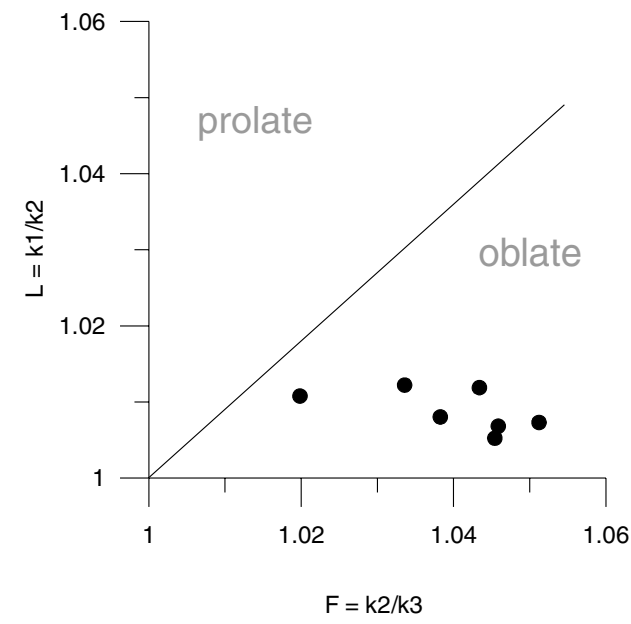

(a)

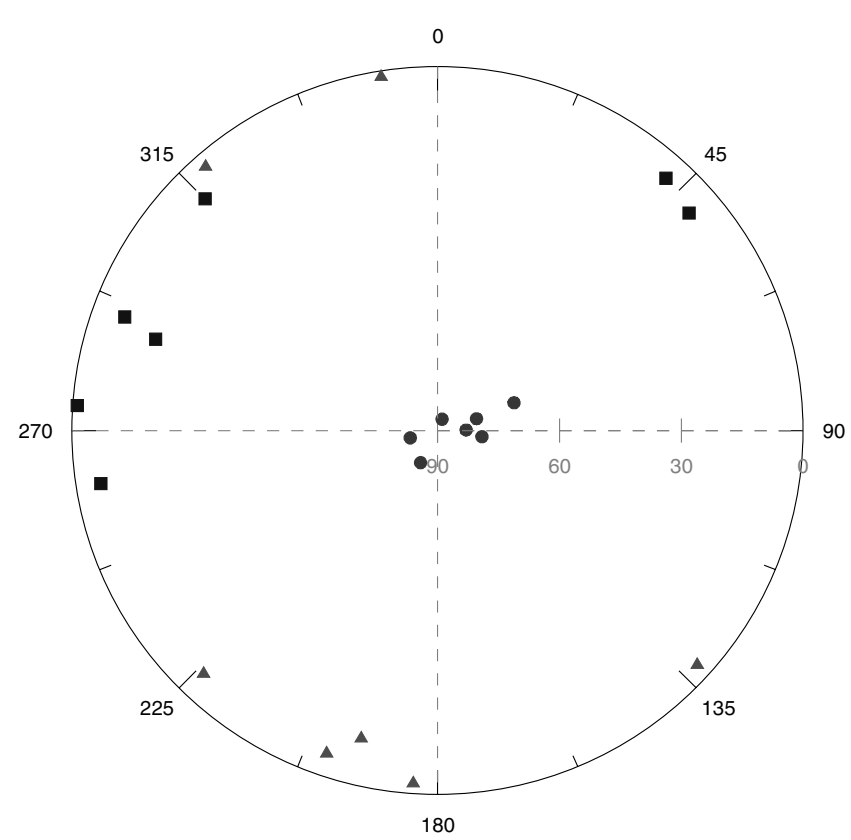

(b)

Figure 7. (a) Flinn-type plot of the degree of lineation (L) and foliation (F), (b) equal-area projection of the principal axes of magnetic susceptibility ellipsoid (Vagnari kiln). Symbols: square $=$ maximum; triangle $=$ intermediate; dot $=$ minimum axis of susceptibility.

last three millennia. The SV curve obtained using Bayesian modelling compared with the French SV curve shows a similar trend but also some important differences. The two curves do not completely coincide in the whole period examined but there is no clear indication of a westward or eastward drift. The preliminary SV curve succeeds in describing the variations of the Earth's magnetic field in the past. However, the large error envelope obtained for certain time periods indicates that caution is needed if used for archaeomagnetic dating, when the maximum precision is required. Undoubtedly more data are still required in order to be able to draw a more detailed SV curve for Italy that will be necessary for improved dating reliability as well as further defining the geomagnetic variation properties.

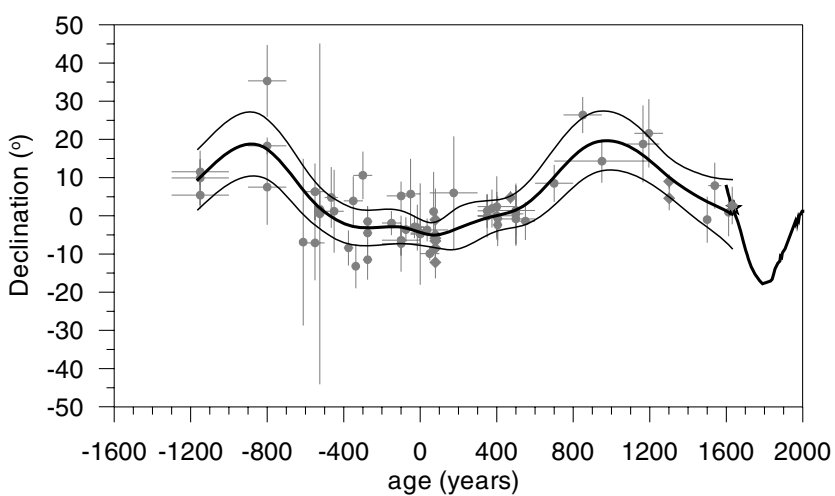

(a)

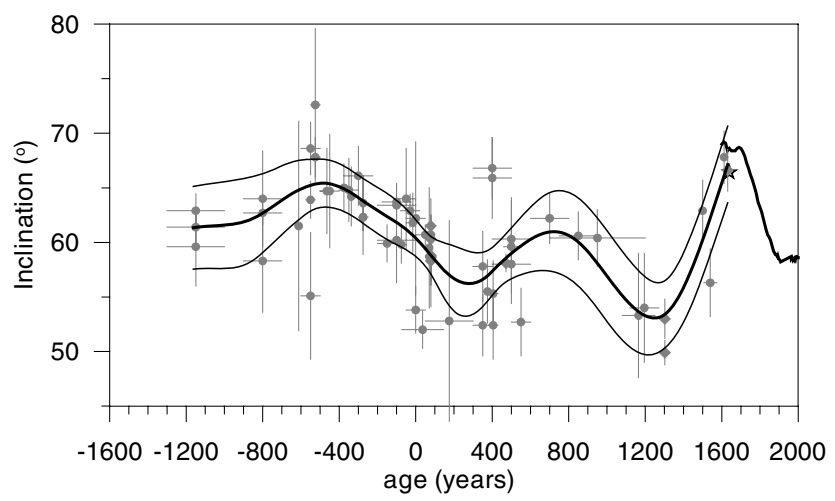

(b)

Figure 8. Smoothed SV curves for (a) declination and (b) inclination for Italy surrounded by the 95 per cent error envelope as obtained from the Bayesian modelling. Together are plotted the raw data and the historical measurements for the last four centuries. All directions are reduced to the reference site Viterbo $\left(42.45^{\circ} \mathrm{N}, 12.03^{\circ} \mathrm{E}\right)$.

\section{A C K NOWLEDGMENTS}

We thank all archaeologists for sampling permission, their collaboration and helpful discussions. R. Lanza is greatly thanked for precious advice and constructive comments on the manuscript. The paper benefited from the reviews of D. Tarling, E. Schnepp and H. Soffel. ET acknowledges a fellowship from the European AARCH Network (Archaeomagnetic Applications for the Rescue of Cultural Heritage), Contract EU: HPRN-CT-2002-00219. The Genève laboratory was supported by FNRS grants: 2.756-0.87, 20-30288.90, 2-0056.43.

\section{R EFER E N CES}

Abdeldayem, A., Tarling, D.H., Marton, P., Nardi, G. \& Pierattini, D., 1992. Archaeomagnetic study of some kilns and burnt walls in Selinunte archaeological township, Sicily, Science and Technology for Cultural Heritage, I, 129-141.

Batt, C.M., 1997. The British archaeomagnetic calibration curve: an objective treatment, Archaeometry, 39, 153-168.

Buck, C.E., Cavanagh, W.G. \& Litton, C.D., 1996. Bayesian Approach to Interpreting Archaeological Data, John Wiley, Chichester.

Bucur, I., 1994. The direction of the terrestrial magnetic field in France during the last 21 centuries, Phys. Earth planet. Inter., 87, 95-109.

Cafarella, L., De Santis, A. \& Meloni, A., 1992. The Historical Italian Geomagnetic Data Catalogue, ING, Rome, p. 160.

Carracedo, J.C., Principe, C., Rosi, M. \& Soler, V., 1993. Time correlation by palaeomagnetism of the 1631 eruption of Mount Vesuvius. 


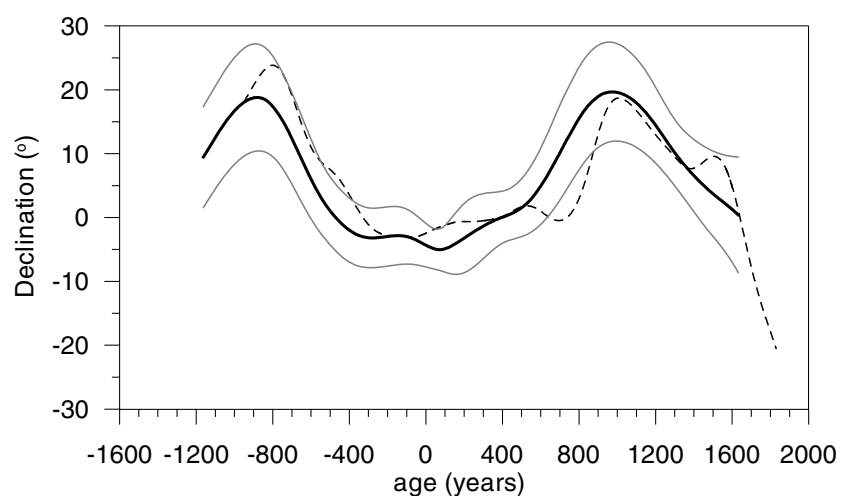

(a)

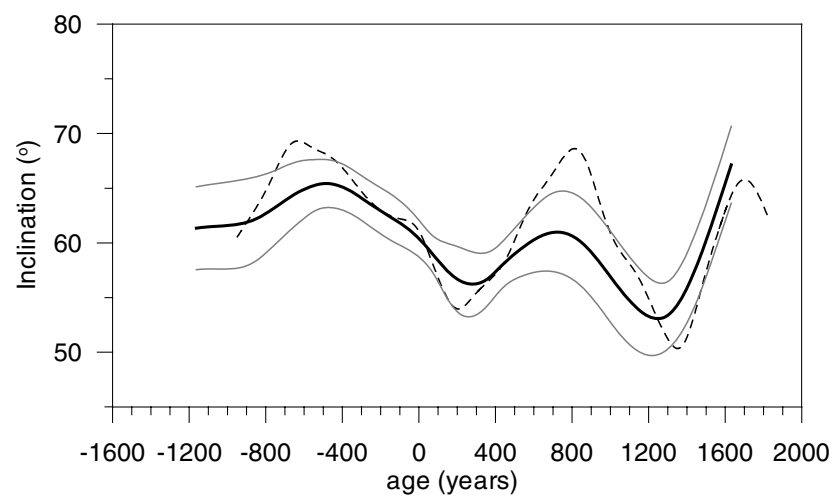

(b)

Figure 9. Declination (a) and inclination (b) of the obtained Italian SV reference curves as in Fig. 8 compared with the French SV curves reduced to Viterbo station (dashed line- data set Gallet et al. 2002).

Volcanological and volcanic hazard implications, J. Volc. Geotherm. Res., 58, 203-209.

Chiari, G. \& Lanza, R., 1999. Remanent magnetization of mural paintings from the Bibliotheca Apostolica (Vatican, Rome), Appl. Geophys., 41, 137-143.

Chiosi, E., La Torre, M., Nardi, G. \& Pierattini, D., 1998. Archaeomagnetic data from a kiln at Cassano (South Italy), Science and Technology for Cultural Heritage, 7(2), 13-17.

Cioni, R., Gurioli, L., Lanza, R. \& Zanella, E., 2004. Temperatures of the A.D. 79 pyroclastic density current deposits (Vesuvius, Italy), J. geophys. Res., 109, $\mathrm{BO} 2207$.

Clark, A.J., Tarling, D.H. \& Noel, M., 1988. Developments in archaeomagnetic dating in Britain, J. Arch. Sci., 15, 645-667.

Cogné, J.P., 2003. PaleoMac: a Macintosh. Application for treating palaeomagnetic data and making plate reconstructions, Geochem. Geophys. Geosyst., 4(1), 1007. doi:10.1029/2001GC000227.

Daly, L. \& Le Goff, M., 1996. An updated and homogeneous world secular variation data base. 1 . Smoothing the archaeomagnetic results, Phys. Earth planet. Int., 93, 159-190.

Evans, M.E. \& Hoye, G.S., 2005. Archaeomagnetic results from southern Italy and their bearing on geomagnetic secular variation, Phys. Earth planet. Inter., 151, 155-162.

Fisher, R.A., 1953. Dispersion on a sphere, Proc. Roy. Soc. London, A, 217, 295-305.

Gallet, Y., Genevey, A. \& Le Goff, M., 2002. Three millennia of directional variation of the Earth's magnetic field in Western Europe as revealed by archaeological artefacts, Phys. Earth planet. Inter., 131, 81-89.

Hoye, G.S., 1981. Archaeomagnetic secular variation record of Mount Vesuvius, Nature, 291, 216-218.

Incoronato, A., Angelino, A., Romano, R., Ferrante, A., Sauna, R., Vanacore, G. \& Vecchione, C., 2002. Retrieving geomagnetic secular variations from lava flows: evidence from Mount Arso, Etna and Vesuvius (southern Italy). Geophys. J. Int., 149, 724-730.

Jackson, A., Jonkers, A.R.T. \& Walker, M.R., 2000. Four centuries of geomagnetic secular variation from historical records, Phil. Trans. R. Soc. Lond., Ser., A, 358, 957-990.

Kent, D.V., Ninkovich, D., Pescatore, T. \& Sparks, S.R.J., 1981. Palaeomagnetic determination of emplacement temperature of Vesuvius AD 79 pyroclastic deposits, Nature, 290, 393-396.

Kovacheva, M., 1997. Archeomagnetic database from Bulgaria, Phys. Earth planet. Inter., 102, 145-151.

Kovacheva, M. \& Toshkov, A., 1994. Geomagnetic field variations as determined from Bulgarian archaeomagnetic data. Part I: the last 2000 years AD, Surv. Geophys., 15, 673-701.

Kovacheva, M., Jordanova, N. \& Karloukovski, V., 1998. Geomagnetic field variations as determined from Bulgarian archaeomagnetic data. Part II: the last 8000 years, Surv. Geophys., 19, 431-460.

Lanos, Ph., 2004. Bayesian inference of calibration curves: application to archaeomagnetism, in Tools for Constructing Chronologies, Crossing Disciplinary Boundaries, Vol. 177, pp. 43-82, eds Buck, C.E. \& Millard, A.R., Series: Lecture Notes in Statistics, Springer-Verlag, London.

Lanos, Ph., Le Goff, M., Kovacheva, M. \& Schnepp, E., 2005. Hierarchical modelling of archaeomagnetic data and curve estimation by moving average technique, Geophys. J. Int., 160, 440-476.

Lanza, R. \& Zanella, E., 2003. Palaeomagnetic secular variation at Vulcano (Aeolian Islands) during the last $135 \mathrm{kyr}$, Earth planet. Sci. Lett., 213, 321-336.

Lanza R., Meloni, A. \& Tema E., 2005. Historical measurements of the Earth's magnetic field compared with remanence directions from lava flows in Italy over the last four centuries, Phys. Earth planet. Inter., 148, 97-107.

La Torre, M., Livadie Arbore, C., Nardi, G. \& Pierattini, D., 1998. Archaeomagnetic study of the Late Archaic furnace of Treglia (Campania, Southern Italy), Sci. Tech. Cultural Heritage, 7(2), 7-12.

Le Goff, M., Henry, B. \& Daly, L., 1992. Practical method for drawing a VGP path, Phys. Earth planet. Int., 70, 201-204.

Le Goff, M., Gallet, Y., Genevey, A. \& Warmé, N., 2002. On archeomagnetic secular variation curves and archeomagnetic dating, Phys. Earth planet. Int., 134, 203-211.

Lowrie, W., 1990. Identification of ferromagnetic minerals in a rock by coercivity and unblocking temperature properties, Geophys. Res. Lett., 17, 159-162.

Márton, P., 2003. Recent achievements in archaeomagnetism in Hungary. Geophys. J. Int., 153, 675-690.

Márton, P., 1996. Archaeomagnetic directions: the Hungarian calibration curve, in Paleomagnetism and Tectonics of the Mediterranean Region, Vol. 105, pp. 385-399, eds Morris, A. \& Tarling, D., Geological Society Special publication.

Márton, P., Abdeldayem, D., Tarling, D.H., Nardi, G. \& Pierattini, D., 1992. Archaeomagnetic study of two kilns at Segesta, Sicily, Sci. Tech. Cultural Heritage, I, 123-127.

Márton, P. \& Ferencz, E., 2006. Hierarchical versus stratification statistical analysis of archaeomagnetic directions: the secular variation curve for Hungary, Geophys. J. Int., 164, 484-489, doi:10.1111/j.1365246X.2006.02873.x

Nardi, G., Pierattini, D. \& Talamo, P., 1995. Archaeomagnetic data from Campania (Southern Italy): the 'Medieval' furnace of Pratola Serra, Avellino, Sci. Tech. Cultural Heritage, 4(I), 71-77.

Noel, M. \& Batt, C.M., 1990. A method for correcting geographically separated remanence directions for the purpose of archaeomagnetic dating. Geophys. J. Int., 102, 753-756.

Principe, C., Tanguy, J.C., Arrighi, S., Paiotti, A., Le Goff, M. \& Zoppi, U., 2004. Chronology of Vesuvius' activity from A.D. 79 to 1631 based on archeomagnetism of lavas and historical sources, Bull. Volcanol., 66, 703-724.

Schnepp, E. \& Lanos, Ph., 2005. Archaeomagnetic secular variation in Germany during the past 2500 years, Geophys. J. Int., 163, 479490. 
Schnepp, E., Pucher, R., Reinders, J., Hambach, U., Soffel, H. \& Hedley, I., 2004. A German catalogue of archaeomagnetic data, Geophys. J. Int., 157, 64-78.

Tanguy, J.C., Bucur, I. \& Thompson, J.F.C., 1985. Geomagnetic secular variation in Sicily and revised ages of historic lavas from Mount Etna. Nature, 318, No. 6045, 453-455.

Tanguy, J.C., Le Goff, M., Principe, C., Arrighi, S., Chillemi, V., Paiotti, A., La Delfa, S. \& Patanè, G., 2003. Archaeomagnetic dating of Mediterranean volcanics of the last 2100 years: validity and limits, Earth planet. Sci. Lett., 211, 111-124.

Tarling, D.H. \& Dobson, M.J., 1995. Archaeomagnetism: an error assessment of fired material observations in the British directional database, $J$. Geomag. Geoelectr., 47, 5-18.

Thellier, E., 1981. Sur la direction du champ magnétique terrestre, en France, durant les deux derniers millénaires, Phys. Earth planet. Inter., 13, 89132.

Thellier, E. \& Thellier, O., 1959. Sur l'intensité du champ magnétique terrestre dans le passé historique et géologique, Ann. Géophys., 15, 285-376.

Zanella, E., Gurioli, L., Chiari, G., Ciarallo, A., Cioni, R., De Carolis, E. \& Lanza, R., 2000. Archaeomagnetic results from mural paintings and pyroclastic rocks in Pompeii and Herculaneum, Phys. Earth planet. Inter., 118, 227-240.

\section{A P PENDIX: ARCHAEOLOGICAL REFERENCES OF THE NEW STUDIED SI T ES}

2: Castelseprio, Varese. Baked clay hearth, US1020, House VI, room 2. TL date Milan, Mi89-Ca4: $1540 \pm 4$ A. D. E. S. Sibilia, L. D. Della Torre, 1989, Notiziario Soprintendenza archeologica Lombardia, 183. (Sampled 1988/7)

3: Rome, Foro Traiano. Brick kiln. Archaeological information suggests that below the structure sampled there is another kiln, probably of a circular shape. Meneghini, R., 1999. Roma- Interventi per il Giubileo del 2000 scavo del monastero di S. Urbano al Foro di Traiano. Archeologia Medievale XXVI, 43-66. (Sampled 2004/5)

4,6,13: Dosso Castello, Piadena. Three horizontal baked clay hearths sampled in the same section exposed in a trench. Based on stratigraphy, from oldest to youngest: E, C, H. TL dates from Milan TL laboratory. M. Martini, E. Sibilia, G. Spinolo. 1985, Notizario Soprintendenza archeologica della Lombardia. p216. (Sampled 1985/7)

12: San Vincenzo, Galliano, Cantu, Como. Hearth inside the church that could possibly be a bell mould. Large samples $(6 \times$ $6 \times 4 \mathrm{~cm}$ ) taken embedded in plaster of Paris. (Sampled 1981/9)

14: Rome, Foro Traiano. Limekiln. Archaeological dating based on the characteristic shape of the structure and also on the later backfill of the kiln missing 'vetrina pesante' potsherds. Meneghini, R., 1998. Roma- Nuovi dati sul medioevo al foro e ai Mercati di Traiano. Archeologia Medievale XXV, 127-141., (Sampled 2004/5)

15: Canosa, Puglia. Kiln for the production of bricks, probably used for the construction of the nearby well-dated church of Saint Sabino. Excavation responsible: Prof. Giuliano Volpe, Universita di Foggia. (Sampled 2003/10)

19, 20: Carlino, Aquileia. Large rectangular kilns in poor state of preservation, so only 7 tiles sampled from kiln 2. Estimation of effect of magnetic anisotropy made but not applied. Luisa Bertacchi. 1976. La ceramica invetriata di Carlino. Aquileia Nostra, p 182-194. (Sampled 1982/6)

24: Vagnari, Puglia. Small kiln in Trench 5. Prof. Alastair Small, University of Edinburgh, Prof. Giuliano Volpe, Universita di Foggia. Vagnari: Il villagio, l'artigianato, la proprietà imperiale. Lo scavo e le strutture, I. Eds. Alastair Small \& Carola Small, in press. (Sampled 2003/7)

25: Ascoli Satriano, Puglia. Archaeological excavation of Faragola. Kiln probably used for the production of tiles and bricks for the construction of a nearby Roman villa. Volpe G., De Felice G., Turchiano M., 2004. I rivestimenti marmorei, $i$ mosaici e i panelli in opus sectile vitreo della villa tardoantica di Faragola (Ascoli Satriano Foggia), in atti del X Colloquio dell' associazione Italiana per lo Studio e la Conservazione del Mosaico (AISCOM) (Lecce 18-21 febbraio 2004), Roma, c.s. (Sampled 2003/7)

27: Lonato, Brescia. Very large circular kiln, $9 \mathrm{~m}$ in diameter, the only one sampled of the several excavated at this workshop. Filli Rossi, 1986. Lonato (Brescia), Località "Fornace dei Gorghi", fornaci romane. Notizario Soprintendenza archeologica della Lombardia, pp. 188-190. Filli Rossi, 1987. Lonato (Brescia), Località Fornace dei Gorghi. Notizario Soprintendenza archeologica della Lombardia, pp. 59-65. (Sampled 1987/10)

33: Marzabotto, Bologna. Large rectangular $(6.9 \times 2.5 \mathrm{~m})$ kiln (Fornace A) protected by metallic roof. Magnetic viscosity estimated using zero field store. All specimens thermally demagnetized but only to $120^{\circ} \mathrm{C}$ because of plastic disc support.Archaeological date is that found in first reference (p391) for kiln B. S. De Maria, G. Sassatelli, D. Vitali. 1976. Studi Etrusci, vol XLIV, ser III, p389391. S. De Maria, 1978. Atti della Accademia nazionale dei Lincei, anno CCCLXXV, Notizie degli scavi di Antichità, ser. 8, vol. 32, pp. 82-91. (Sampled 1982/6)

53: Pozzuolo del Fruili, Udine. The baked clay from this oven (No. 8) has an important viscosity, so only 4 of the 8 specimens accepted. A.-M. Adam, P. C. Guida et S. Vitri. L'insediamento protohistorico di Pozzuolo del Friuli (Udine). Bollettino della Societa Adriatica di Scienze LXIX, 67-75, 1986/87. (Sampled 1988/7)

55: Chiesa San Francesco, via Beato, Odorico da Pordenone, Udine. Well baked hearth (TRA/ $\alpha$ ), US6.under pavement inside church. (Sampled 1988/7)

58: Este-Casa di Ricovero, Padova. US 169, square I40 near tomb 98. Baked clay from this structure has a high magnetic viscosity and probably has not been heated to a high enough temperature and this is responsible for the large dispersion of directions. Sampled 1988/9)

60: Arcora, Campomarino, Molise. Remarkable thick well-baked clay hearth. US 2, square E VIII.13. A.di Niro, 1991. Il villagio protohistorico di Campomarino. In Samnium, Archeologia del Molise, Roma, pp. 35-47. (Sampled 1993/7)

61: Montagnana, - Borgo San Zeno. Two hearths sampled in protohistoric village but only US137 (G.885/C3) gives an acceptable result. (Sampled 1988/8)

62, 63, 64: Scarceta, Manciano-Grosseto, Toscane. Hard baked clay hearths, late Bronze Age. Trincea D5-3, 1: well-preserved flat hearth exposed in trench. Some evidence of bronze working. One specimen AF demagnetised, rest heated to $120^{\circ} \mathrm{C}$. Square D 5-4, 2: flat hearth with broken surface. Square D 6-3, 3: smaller flat hearth, poorly preserved. (Sampled 1982/8)

65: Grotta dell'Edera di Aurisina, Trieste. Structure 2. Only one hearth was sampled of the many visible in section of sedimentary deposit inside cave. Archaeological age: Neolithic to Chalcolithic. $\mathrm{C}_{14} 4680 \pm 325$ BP Geochron GX-19019 (Sampled 1993/9)

66, 67: Laghetti del Crestoso, Bovegno, Brescia. When sampled in October 1988 these were the only Mesolithic hearths known in the Alps. $\mathrm{C}_{14} 6790 \pm 120 \mathrm{BP}$ (HAR 887-1). Hearths are made up of sandy sediment. Specimens generally have a low remanence and some have appreciable magnetic viscosity. Baroni et al. 1987, Scavi di età preistorica e protohistorica. Notizario Soprintendenza archeologica della Lombardia, 15-17. Baroni et al. 1990. Laghetti 
del Crestoso : a high-altitude Castelnovian camp in its environmental setting. In The Neolithisation of the Alpine region Biagi P. (ed.) Monographie di "Natura Bresciana", 13, 43-51. Excavations at the high altitude Mesolithic site of Laghetti del Crestoso, Bovegna, Brescia -Northern Italy. Ateneo di Brescia Accademia di Scienze Lettere ed Arte, pp. 101-102, 1997.

72, 73: Castelgoffredo, Piazza Gonzaga, Mantova. Flat baked clay hearths exposed in the wall of a deep trench. US 1226, settore A/sezione N. US 1205, settore A/sezione W. Koenigsberger ratio
Qn and viscosity measurements indicate that 1226 has been heated more than 1205. A. Breda, 1986. Castelgoffredo (Mantova) Piazza Gonzaga. Edificio altomedievale. Notiziario Soprintendenza archeologica della Lombardia, pp. 94-96. (Sampled 1986/4)

74: Massinigo, San Margherita di Staffora, Pavia. Large kiln 4 $\mathrm{m}$ in diameter protected inside a building. Sun compass used for orientation of 4 of the 8 practically horizontal tiles removed from the kiln. N. Cuomo di Caprio. 1971-1972 Proposta di classificazione delle Fornaci. Sibrium XI pp. 423-425. (Sampled 1981/9) 